\title{
Modern trends in the formation of economic and organizational foundations for the construction and development of the digital economy in the Republic of Kazakhstan ${ }^{1}$
}

\author{
Yersultan Beisembay, Takhir Yazdurdievich Ernazarov \\ Toraighyrov University
}

\begin{abstract}
The article discusses modern trends in the formation of economic and organizational foundations for the construction and development of the digital economy in Kazakhstan considering the ongoing market reforms. The object of the research is the trends in the digitalization of the economy. The subject of the research is the economic and organizational foundations of digitalization. Particular attention is focused on the fundamental foundations of the transformation of the economy from a traditional type to an economy based on digital information, the production of Internet of things. As part of the research, the trends in the functioning of the leading subsectors of the digital economy, such as the production of computers, digital equipment, digital goods and services, and software have analyzed. The assessment of the direct contribution of digitalization processes to the GDP of the Republic of Kazakhstan and economic growth was also carried out. As the leading organizational foundations for the construction and development of the digital economy, the infrastructural foundations of providing the economy with digital communications are identified and analyzed, the trends in the formation of the institutional foundations of digital business and entrepreneurship based on the use of the global Internet and its derivatives in the system of business processes of Kazakhstani enterprises, firms, companies are discussed. The study, on the one hand, allows us to form a general comprehensive understanding of the current state of formation and functioning of the digital economy of the Republic of Kazakhstan, the types of functioning digital markets, and on the other hand, it allows us to determine the totality of existing potential problems and reserves for the development of digitalization of the economic system in the near strategic perspective. The main research methods were analytical and synthetic, statistical, computational, and analytical research methods, the method of hypotheses.
\end{abstract}

Keywords: Digital economy; digital market; digital goods; digital services; online shopping; the digital economy; digitization of business processes.

\section{Қазақстан Республикасында цифрлық экономиканың құрылысы мен дамуының экономикалық және ұйымдастырушылық негіздерін қалыптастырудың қазіргі заманғы тенденциялары}

Түйін

Мақалада жүргізіліп жатқан нарықтық реформаларды ескере отырып, Қазақстан Республикасында цифрлық экономиканы құру мен дамытудың экономикалық және ұйымдастырушылық негіздерін қалыптастырудың қазіргі заманғы тенденциялары талқыланады. Зерттеу нысаны - экономиканы цифрландыру үрдістері. Зерттеу пәні - цифрландырудың экономикалық және ұйымдастырушылық негіздері. Ерекше назар экономиканы дәстүрлі типтен цифрлық ақпаратқа негізделген экономикаға трансформациялаудың, интернетті өндірудің іргелі негіздеріне бағытталған. Зерттеу шеңберінде цифрлық экономиканың жетекші кіші секторлары жұмысының тенденциялары талданды, мысалы, компьютерлер, цифрлық жабдықтар, цифрлық тауарлар мен қызметтер, бағдарламалық қамтамасыз ету. Цифрландыру процестерінің Қазақстан Республикасының ЖІӨне және экономикалық өсімге қосқан тікелей үлесіне бағалау жүргізілді. Цифрлық экономиканы құру мен дамытудың жетекші ұйымдастырушылық негіздері ретінде экономиканы цифрлық коммуникациялармен қамтамасыз етудің инфрақұрылымдық негіздері анықталып, талданған, цифрлық бизнес пен кәсіпкерліктің институционалдық негіздерін қалыптастыру тенденциялары ғаламдық Интернет және оның қазақстандық кәсіпорындардың, фирмалардың, компаниялардың бизнес-процестер жүйесіндегі туындылары талқыланады. Зерттеу, бір жағынан, Қазақстан Республикасының цифрлық экономикасының қалыптасуы мен жұмыс істеуінің қазіргі жағдайы, цифрлық нарықтардың жұмыс істеп тұрған түрлері туралы жалпы жан-жақты түсінік қалыптастыруға мүмкіндік береді, ал екінші жағынан, жақын арадағы стратегиялық перспективада экономикалық жүйені цифрландыруды дамыту үшін бар ықтимал проблемалар мен резервтердің жиынтығын анықтауды көздейді. Зерттеудің негізгі әдістері мыналар болды: аналитикалық және синтетикалық, статистикалық, есептеу және аналитикалық зерттеу әдістері, гипотезалар әдісі.

Түйін сөздер: цифрлық экономика; цифрлық нарық; цифрлық тауарлар; цифрлық қызметтер; Интернетсауда; бизнес-процестерді цифрландыру.

1 The study was conducted in the framework of extra-budgetary sources of funding in the framework of doctoral studies at $\mathrm{PhD}$ Toraighyrov University in the field of economics.

During the research and writing of the scientific article, the advisory support was provided by the leading departments of economics of Toraighyrov University. 


\title{
Современные тенденции формирования экономических и организационных основ построения и развития цифровой экономики в Республике Казахстан
}

\begin{abstract}
Аннотация
В статье рассмотрены современные тенденции формирования экономических и организационных основ построения и развития цифровой экономики в Республике Казахстан с учетом проводимых рыночных реформ. Объектом исследования выступают тенденции цифровизации экономики. Предмет исследования - экономические и организационные основы цифровизации. Особое внимание акцентировано на фундаментальных основах трансформации экономики от традиционного типа к экономике, основанной на цифровой информации, производстве интернет-вещей. В ходе проводимого исследования проанализированы тренды функционирования ведущих подотраслей цифровой экономики, таких как производство компьютеров, цифрового оборудования, цифровых товаров и услуг, программного обеспечения. Также выполнена оценка непосредственного вклада процессов цифровизации в ВВП Республики Казахстан и экономический рост. В качестве ведущих организационных основ построения и развития цифровой экономики обозначены и проанализированы инфраструктурные основы обеспечения экономики цифровыми коммуникациями, затронуты тенденции формирования институциональных основ цифрового бизнеса и предпринимательства на основе использования глобальной сети Интернет и ее производных в системе бизнес-процессов казахстанских предприятий, фирм, компаний. Проведенное исследование, с одной стороны, позволяет сформировать общее комплексное представление о современном состоянии формирования и функционирования цифровой экономики Республики Казахстан, видах функционирующих цифровых рынках, а с другой стороны позволяет определить совокупность существующих потенциальных проблем и резервы развития цифровизации экономической системы на ближайшую стратегическую перспективу. В качестве основных методов исследования выступили аналитический и синтетический, статистический, расчетно-аналитический методы исследования, метод гипотез.
\end{abstract}

Ключевые слова: цифровая экономика; цифровой рынок; цифровые товары; цифровые сервисы; онлайн коммерция; цифровая экономика; цифровизация бизнес-процессов.

\section{Introduction}

At the present stage, in the context of the growing trends of the fourth scientific and technological revolution, in the global world economy, there are active processes of transition of economic systems to a cardinal level of a new quality - a digital economy based on Internet technologies, electronic business and e-commerce, electronic automation of production and economic processes in the system of functioning of enterprises and sectors of the economy.

Considering the close integration of the Republic of Kazakhstan into global economic processes, it is important to build and develop the digital economy at the national, sector and intersectoral levels.

To build and develop the digital economy in the Republic of Kazakhstan at the state level, special targeted strategic programs have been developed and adopted - Information Kazakhstan - 2020, Digital Kazakhstan. These programs are at the stage of initial implementation and issues of mechanisms for their effective implementation are being worked out.

To build and develop the digital economy in the Republic of Kazakhstan require an in-depth analysis and assessment of the impact of the digitalization of the economy on all aspects of production, economic and socio-economic subsystems with the consistent development of transformation mechanisms from a traditional economy to an economy based on the complex application of digital technologies. In the future, the progressive development of the digital economy, markets for digital products and services, the Internet of things should intensively contribute to an increase in the level of innovation and competitiveness of the Republic of Kazakhstan, a significant increase in the quality of life of the population.

The purpose of this study is to analyze current trends in the formation of the economic and organizational foundations for the development of the digital economy in the Republic of Kazakhstan and to identify the main problems in these areas. This will identify ways to accelerate the transformation of the economy from a traditional type to an economy based on digital technologies.

\section{Literature review}

The digital economy in modern models of activity in various countries of the world is considered as a new stage in the evolution of production and economic activities and social activities of society. The digital economy fully complies with the global trends of the Fourth Industrial Revolution (Industry 4.0).

According to generally accepted encyclopedic data, the digital economy is a process of the functioning of an economic system based on the complex application of computer hardware, software, digital communications, and network communications [1].

The initial scientific approach to understanding the essence of the digital economy was proposed by the American computer scientist-programmer Nicholas Negroponte. The following was identified as the main postulates of the innovation economy: minimization of the material physical condition 
of goods and services (minimization of weight, raw materials, and materials); minimizing the importance of raw materials and supplies in the manufacturing process; creation of intangible or partially material goods with elements of virtual reality; instant movement of goods and services from producer to consumer [2].

It should be noted that in the modern scientific community, there is a tendency that as such, a clearly defined concept of "digital economy" does not exist, and the determinants that take place are multifactorial.

Candidate of Economic Sciences, Associate Professor of the Moscow State University named after M.V. Lomonosova A. Engovatova, formulates a scientific hypothesis that the digital economy is a set of radically new methods of accumulating information data, in the process of using which all aspects of business processes of business entities undergo changes [3].

Associate Professor of Omsk State Technical University Kaluzhsky M.L. considers the digital economy as a communication environment associated with the global Internet, which has tools for its effective and purposeful use [4].

In a way, a unique point of view regarding the understanding of the digital economy is held by the American scientist, futurologist, specialist in the field of cybernetics Kelly K., who compares the digital economy with the totality of all communications that act as the core, the center of attraction of all other elements of the digital economy $[5,6]$.

Most scientists consider the science of satisfying the needs of all its subjects using digital information and the corresponding digital infrastructure as the essence of the digital economy $[7,8]$.

In the scientific works of scientists dedicated to the digital economy, certain scientific views are devoted to the formation of the organizational and economic foundations of digitalization. So, in a scientific article Litvinenko V. S. notes that the digital economy needs to be integrated with research and production structures, research centers, while a certain system of personnel training should be formed [9]. Scientists Nosova S.S., Makar S.V., Gerasimenko T.I., Medvedeva O.E., Abdulov R.E. emphasize that to build and develop the digital economy, possible variable business models must be worked out [10]. Several other scientists from far abroad believe that the digital economy, from an organizational point of view, must go through three stages: digitization, digitalization, and digital transformation. In the process of digitalization, the maximum investment potential should be used [11, 12].

\section{Methodology}

The main research methods were analytical and synthetic, statistical, computational and analytical research methods, the method of hypotheses. The hypothesis design method was also used. Within the framework of the analytical research method, all the constituent elements of the economic and organizational foundations of the Republic of Kazakhstan were analyzed separately. The analytical method made it possible to determine the problematic organizational and economic points of the functioning of the digital economy. The analytical method was coupled with the statistical research method and the calculationanalytical method when specifying certain indicative indicators. Based on the analytical method, the hypothesis method was applied. Within the framework of the main hypothesis, it was determined that the digital economy of Kazakhstan needs significant infrastructural reforms at the micro levels: Internet resources and digital communications of enterprises, firms, companies; elaboration of an investment strategy in the qualitative development of the computer equipment park of Kazakhstani organizations.

\section{Results and discussion}

The construction and development of the digital economy of the Republic of Kazakhstan took place in parallel with the global, world trends in the evolution of the digitalization of economic systems.

The basic economic foundations for building and developing the digital economy were:

- formation of an offer of digital equipment, digital goods;

- formation of the offer of digital services, digital information;

- production of digital equipment, digital goods, services;

- the formation of demand for digital equipment, digital goods, and services.

Trends in the formation of supply and demand for digital equipment, goods and services created the foundations for the emergence of the first Kazakhstani digital market, which contributed to employment of the population in the primary sectors of the digital economy and the dynamic growth of demand for all types of digital products.

The development of international trade, the integration of the Republic of Kazakhstan into the international trade system played a significant role in the formation of the economic foundations for the construction and development of the digital economy.

The basic organizational structures and development of the digital economy were: 
- organization of supplies of digital equipment, digital goods;

- the emergence (creation) of trade enterprises selling digital equipment, digital goods and services;

- the emergence (creation) of manufacturing enterprises (production of digital equipment, digital goods and services);
- formation of the infrastructural foundations of digitalization (digital communications, digital communications);

- creation of the foundations of state regulation and assistance to the development of the digital economy (Figure 1).

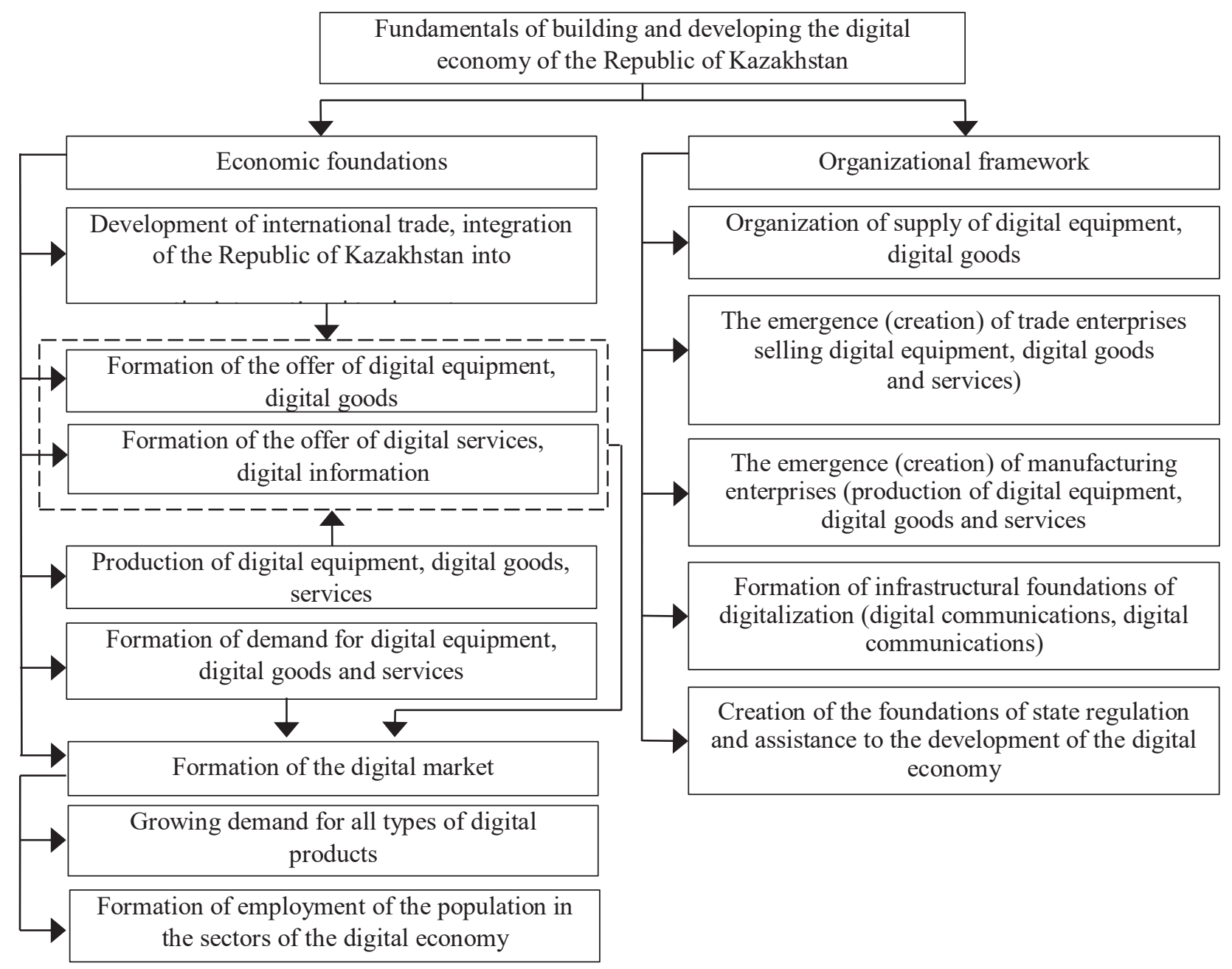

Figure 1 - Systematization of the economic and organizational foundations for the construction and development of the digital economy of the Republic of Kazakhstan

Note - Compiled by the author

During the formation and development of market relations in the Republic of Kazakhstan, since 1993, the formation of the supply of digital equipment, digital goods, as well as digital services, digital information took place due to import supplies from countries of the far and near abroad (Russian Federation). The first representatives of digital products were all types of computer technology.

During the period of the beginning of market reforms, the offer in the digital market of the Republic of Kazakhstan was presented:
- computers;

- computer peripheral equipment;

- computer office equipment;

- multipurpose software.

During the period of deepening market reforms, as of 2001, the size of the computer market was 101254,5 units, and the annual market growth had a trend of $11.6 \%$. In 2019 year, compared to 2001 year, the volume of computer sales has tripled and averaged 300,000 computers (Figure 2). This fact testified to the progressive expansion and development of the computer hardware market. 


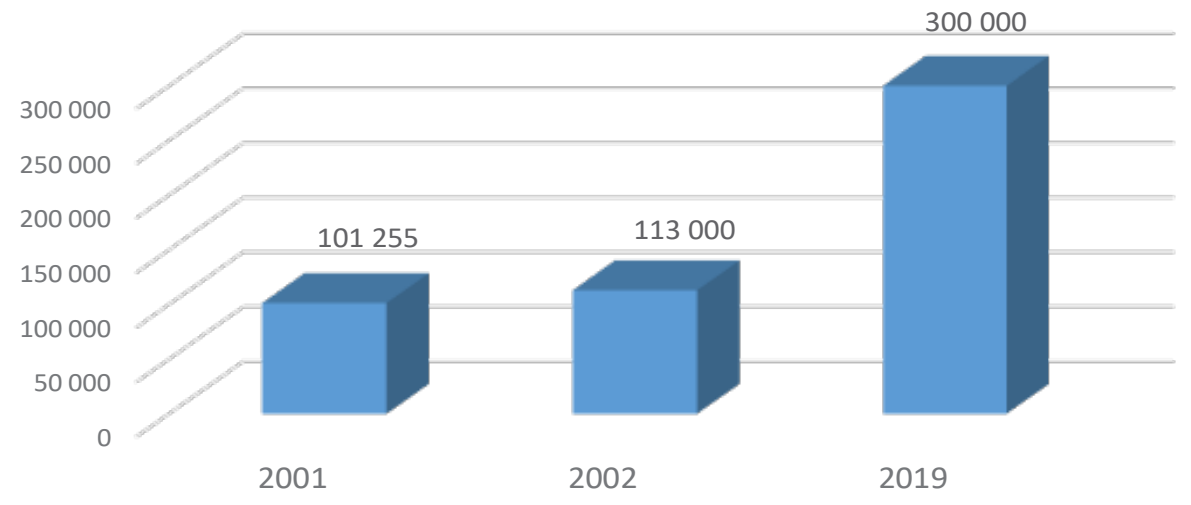

Figure 2 - Dynamics of sales of computers on the market in the Republic of Kazakhstan, during the period of deepening market reforms

Note - Compiled in accordance with source $[13,14,15]$

At all stages of market reforms, the formation of the digital market in the Republic of Kazakhstan was and is in direct dependence on the import of computer equipment. The maximum volumes of imports of computers and related equipment fell during the period 2013 - 2015 (Table 1).

The positive dynamics of imports of computers in these periods was due to the expansion of the boundaries of international cooperation and international trade. Import of computer equipment falls on the leading countries to produce electronics: China, Taiwan, Malaysia, Singapore. For 2016 year, the volume of imports of computers has decreased due to the devaluation of the national currency and a significant increase in prices for imported equipment. As the dynamics of computer imports shows, there was a cyclical nature of their purchase by end consumers.

Table 1 - Dynamics of import of computers and computer equipment assembled to the Republic of Kazakhstan

\begin{tabular}{|l|c|c|c|c|c|c|c|}
\hline \multirow{2}{*}{ Indicator } & \multicolumn{7}{c|}{ Years } \\
\cline { 2 - 8 } & 2013 & 2014 & 2015 & 2016 & 2017 & 2018 & 2019 \\
\hline $\begin{array}{l}\text { Import of computers and related } \\
\text { equipment, USD million }\end{array}$ & 436,7 & 627,2 & 403 & 224,4 & 249,5 & 285,9 & 319,6 \\
\hline Import growth rate, \% & 149,4 & 143,6 & 64,3 & 55,7 & 111,2 & 114,6 & 111,8 \\
\hline \multicolumn{2}{|l|}{ Note - Compiled in accordance with sources [14, 15]. } \\
\hline
\end{tabular}

In our opinion, the cyclical demand for computers will take place on a systematic basis, since there is obsolescence of computer equipment. In the Republic of Kazakhstan, the permissible annual level of depreciation of computer equipment, including software, is $40 \%$, which in turn determines its minimum permissible service life of 2.5 years [16].

In the Republic of Kazakhstan, the necessary organizational foundations have been created and are evolving to update and meet the demand for computer technology. There is a wide network of retail operators, such as: Technodom; Shop. kz; Alser; Sulpak; Fora.

The trends of obsolescence of computers and related computer equipment will contribute to the relevance of its renewal every 2,5-3 years.

Along with import trends, the Republic of Kazakhstan formed its own production facilities to produce computers. It should be noted that from the period 1990 to the present, the production of computers is not accompanied by a full production cycle but is focused on the assembly processes from imported components and peripheral equipment. The production of individual components used in the production of computers is presented in a minimum volume.

The dynamics of the production of computers and related computer equipment in the Republic of Kazakhstan are cyclical, but in the complex, it is characterized by positive trends. The maximum volumes of production of computer equipment were in 2015 and 2019. The maximum production of electronic elements and computer motherboards took place in 2015 and accounted for more than $50 \%$ of the total production of computer equipment (Table 2). 
Table 2 - Dynamics of production of computers and related computer equipment in the Republic of Kazakhstan, million tenge

\begin{tabular}{|l|c|c|c|c|c|}
\hline \multicolumn{1}{|c|}{ Indicator } & \multicolumn{5}{c|}{ Years } \\
\cline { 2 - 6 } & 2015 & 2016 & 2017 & 2018 & 2019 \\
\hline $\begin{array}{l}\text { Manufacture of computers and peripheral equip- } \\
\text { ment }\end{array}$ & 4327,6 & 3210,9 & 2807,3 & 3638,3 & 5537,1 \\
\hline $\begin{array}{l}\text { Manufacture of electronic components and com- } \\
\text { puter motherboards }\end{array}$ & 2226,2 & 159,8 & 124,7 & 11,3 & 426,9 \\
\hline Total & 6553,80 & 3370,70 & 2932,00 & 3649,60 & 5964,00 \\
\hline \multicolumn{1}{|l|}{ Note - Compiled from source [15]. }
\end{tabular}

Both the oldest enterprises producing computers and computer equipment, as well as new ones, conduct industrial and commercial activities in the Kazakhstani digital market. For example, firm KIP LLP and Logycom JSC are among the oldest companies producing computers. These enterprises have been operating since 1990 and 1992, respectively. Among all enterprises in terms of production capacity, JSC "Logycom" is in the lead. The production capacity of this enterprise is estimated at 900 thousand personal computers per year, with the level of pure Kazakhstani production of components reached at $25 \%$ [17].

In 2020, in Kazakhstan, based on the production facilities of JSC "Plant named after S.M. Kirov" in the city of Petropavlosk, a new production of computer equipment was launched under the brand" ZIK computers "[18]. Considering this project, the share of Kazakhstani computers in the total volume of sold computer equipment was brought to $30 \%$ (Figure 3 ).

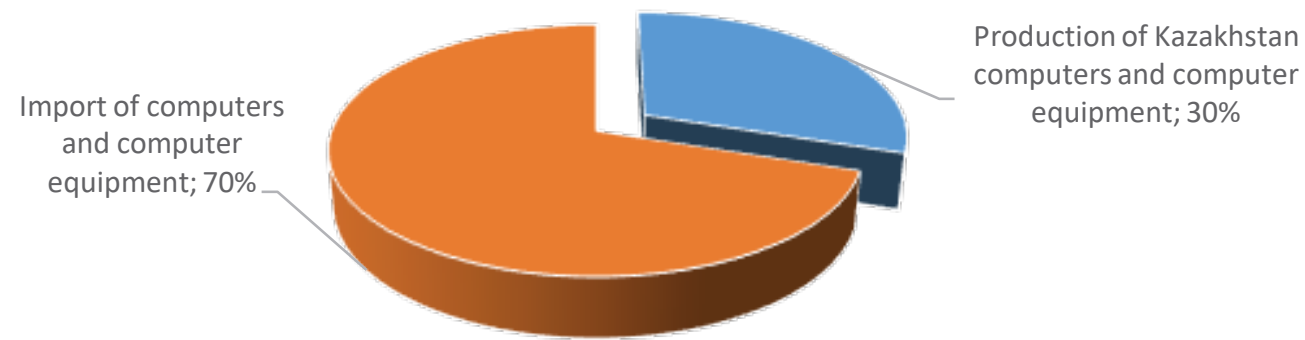

Figure 3 - Structure of the supply of computers and computer equipment in the context of computers made in Kazakhstan and imported from abroad as of 2020 year

Note - Compiled in accordance with source [18]

The formation of the supply of computers and related computer equipment influenced the formation of demand for computer equipment from potential consumers. At the present stage, $82.2 \%$ of all citizens aged 6 to 74 years old are computer users, while at the age from 6 to 15 years old, $80.8 \%$ of the population use computers, which, in our opinion, is a high indicator (Table 3 ).

Table 3 - Dynamics of the share of computer users (individuals) in the Republic of Kazakhstan, \%

\begin{tabular}{|l|c|c|c|c|c|c|c|}
\hline \multicolumn{1}{|c|}{ Indicator } & \multicolumn{5}{c|}{ Years } \\
\cline { 2 - 8 } & 2013 & 2014 & 2015 & 2016 & 2017 & 2018 & 2019 \\
\hline $\begin{array}{l}\text { Computer users between the ages of 6 and 74, } \\
\text { including: }\end{array}$ & 63,2 & 64,1 & 74,2 & 76,2 & 78,2 & 80,3 & 82,2 \\
\hline - computer users aged 6 to 15 & 50 & 52,8 & 60,5 & 65,3 & 73,8 & 76,9 & 80,8 \\
\hline - computer users aged 16 to 74 & 65,9 & 66,5 & 77,2 & 78,7 & 79,3 & 81,2 & 82,5 \\
\hline \multicolumn{7}{|l|}{ Note - Compiled in accordance with sources [14, 15]. } \\
\hline
\end{tabular}


The study shows that at the present stage and in the near future, the level of user activity by computers on the part of the population will grow under the influence of market development and the processes of scientific and technological progress.

Despite the high level of acquisition of user skills for working on computers, the percentage of provision of the population of Kazakhstan remains at a low level. From 2015 to 2019 , the average level of household wealth increased from $36.4 \%$ to $48.3 \%$. As of 2019 , the maximum level of provision of households with computers is in the following types:

- desktop computers - 54.2\%;

- laptops - $55 \%$.

Households are provided with tablet computers to a minimum $-35.8 \%$ (Table 4 ).

Table 4 - Dynamics of the provision of household computers in the Republic of Kazakhstan, \%

\begin{tabular}{|l|c|c|c|c|c|}
\hline \multicolumn{1}{|c|}{ Index } & \multicolumn{4}{|c|}{ Years } \\
\cline { 2 - 6 } & 2015 & 2016 & 2017 & 2018 & 2019 \\
\hline Average level of household computer provision, including: & 36,4 & 44,9 & 45,3 & 46,4 & 48,3 \\
\hline - desktop computers & 54,1 & 58,0 & 55,2 & 54,3 & 54,2 \\
\hline - laptops & 33,2 & 44,7 & 48,4 & 51,1 & 55,0 \\
\hline - tablet computers & 22,0 & 32,1 & 32,2 & 33,8 & 35,8 \\
\hline Note - Compiled from source [15]. & & & & & \\
\hline
\end{tabular}

In the Republic of Kazakhstan, there is a quantitative increase in the computer equipment park in all types of organizations. From 2013 to 2019 , the growth of the computer hardware park grew slightly from 884.9 thousand units. up to 1108.4 thousand units. At the same time, the maximum growth rate of the computer hardware park was in 2013 (Table 5).

Table 5 - Dynamics of the number of computers in organizations of the Republic of Kazakhstan

\begin{tabular}{|c|c|c|c|c|c|c|c|}
\hline \multirow{2}{*}{ Index } & \multicolumn{7}{|c|}{ Years } \\
\cline { 2 - 9 } & 2013 & 2014 & 2015 & 2016 & 2017 & 2018 & 2019 \\
\hline $\begin{array}{l}\text { Total number of computers in organizations of } \\
\text { the Republic of Kazakhstan, thousand units }\end{array}$ & 884,9 & 882,7 & 935,3 & 951,8 & 977,2 & 1042,8 & 1124,1 \\
\hline Growth rate of the number of computers, \% & 140,1 & 99,8 & 106,0 & 101,8 & 102,7 & 106,7 & 107,8 \\
\hline Note - Compiled from sources [14, 15]. & \multicolumn{10}{|c|}{} \\
\hline
\end{tabular}

Studies show that, on average, as of 2019 , there are about two computers per organization in Kazakhstan, which is a low indicator (Table 6).

The low level of provision of Kazakhstani organizations with computer equipment, in our opinion, is associated with such factors as:

- a high level of inflationary processes and a constant rise in the cost of computer equipment due to direct import supplies of computers and components;

- high rates of obsolescence of computer equipment;

- insufficient reserves of profit of enterprises, firms, companies for systematic investments in the renewal of the computer equipment park.

The deepening of the economic and organizational foundations for building and developing the digital economy, along with the import and production of computer equipment, took place in the following areas:
- the emergence and development of the Internet in the country;

- creation of the necessary infrastructural foundations for digital communications;

- production and sale of multipurpose software, provision of additional services;

- development of online commerce;

- digitalization of the activities of public and private organizations;

- the emergence of the Internet of Things market.

As of 2020, the coordination of the Kazakh Internet is carried out by the Ministry of Digital Development, Innovation and Aerospace Industry of the Republic of Kazakhstan. The primary leading provider of the global Internet network in the Republic of Kazakhstan is the national company Kazakhtelecom JSC. 
Table 6 - Assessment of the dynamics of the level of provision of organizations of the Republic of Kazakhstan with computers

\begin{tabular}{|l|c|c|c|c|c|c|c|}
\hline \multicolumn{1}{|c|}{ Indicator } & \multicolumn{5}{c|}{ Years } \\
\cline { 2 - 8 } & 2013 & 2014 & 2015 & 2016 & 2017 & 2018 & 2019 \\
\hline $\begin{array}{l}\text { Total number of computers in organizations of } \\
\text { the Republic of Kazakhstan, thousand units }\end{array}$ & 884,9 & 882,7 & 935,3 & 951,8 & 977,2 & 1042,8 & 1124,1 \\
\hline $\begin{array}{l}\text { Number of organizations in the Republic of } \\
\text { Kazakhstan, thousand units }\end{array}$ & 338,9 & 353,8 & 360,3 & 383,9 & 412,7 & 433,8 & 446,7 \\
\hline $\begin{array}{l}\text { The level of provision of organizations of the } \\
\text { Republic of Kazakhstan with computers, units } \\
\text { / organization }\end{array}$ & 3 & 2 & 3 & 2 & 2 & 2 & 3 \\
\hline \multicolumn{2}{|l|}{\begin{tabular}{l} 
Note - Compiled from sources [15, 19, 20,21]. \\
\hline
\end{tabular}}
\end{tabular}

In the Republic of Kazakhstan, the Internet is in great demand from both individuals and legal entities. From 2015 to 2019, the volume of services provided for access to the Internet increased from 190,4 billion tenge to 282,3 billion tenge (Figure 4).

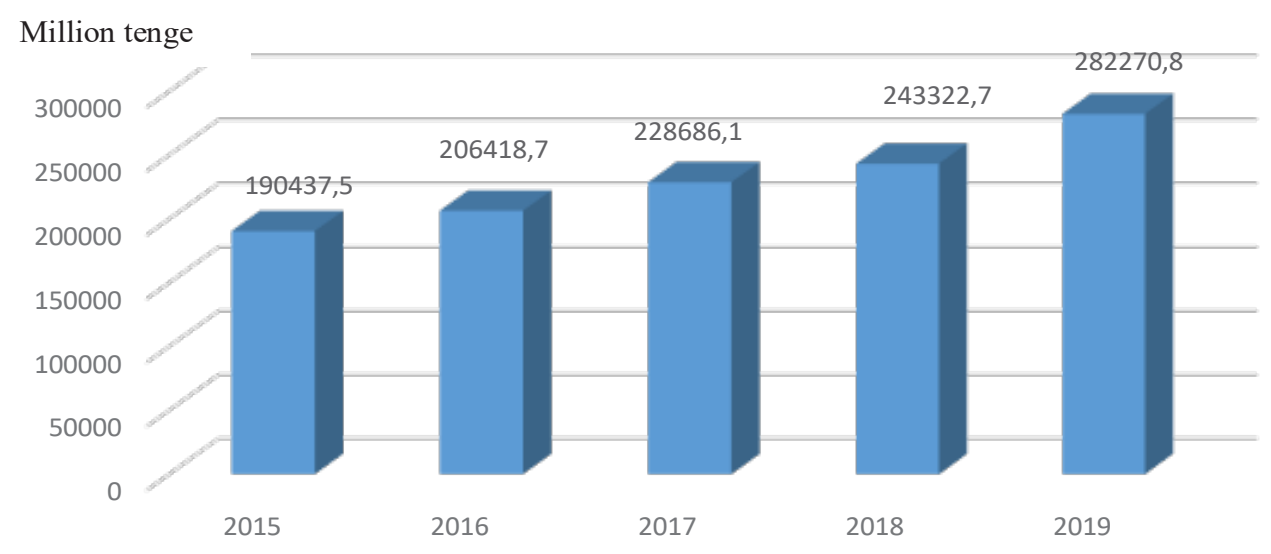

Figure 4 - Dynamics of the provision of services for access to the Internet in the Republic of Kazakhstan

Note - Compiled from source [15]

The level of Internet provision of households and organizations of all types and forms of ownership as of 2019 is $90.3 \%$ and $81.1 \%$, respectively [15].

In the digital market of the Republic of Kazakhstan, the development and expansion of services for access to the global network was accompanied by the emergence of a range of services related to the production and sale of software.

In the area of software offerings, the maximum sales are in the following categories:

- services for the publication of ready-made software for tools and programming languages $35 \%$;

- services for the publication of ready-made application software - $27 \%$;

- services for the provision of licenses for the right to use software - 14\% (Figure 5).

In the digital market of the Republic of Kazakhstan, such additional services are being developed as:
- digital communication services;

- services in computer programming, consulting;

- services for the placement and processing of data, placement of web portals;

- repair of computers and digital communication equipment.

This range of services allows Kazakhstani organizations, large, small, and medium-sized businesses to master technologies for building and designing their own Internet resources. The share of organizations with Internet resources is characterized by a low indicator $-6.3 \%$ (Table 7).

In the system of activities of Kazakhstani organizations, there is a positive trend in the introduction and development of Intranet and Extranet technologies. The share of Kazakhstani organizations with these technologies, as of 2017, amounted to $31.6 \%$ and $3.2 \%$, respectively (Table 8). 
Internet commerce is at the stage of formation and development in the Republic of Kazakhstan. This is evidenced by the degree of Internet use in such target consumer areas as: the purchase of goods and services; sale of goods and services. These indicators are $15.6 \%$ and $12.5 \%$, respectively (Table 9).

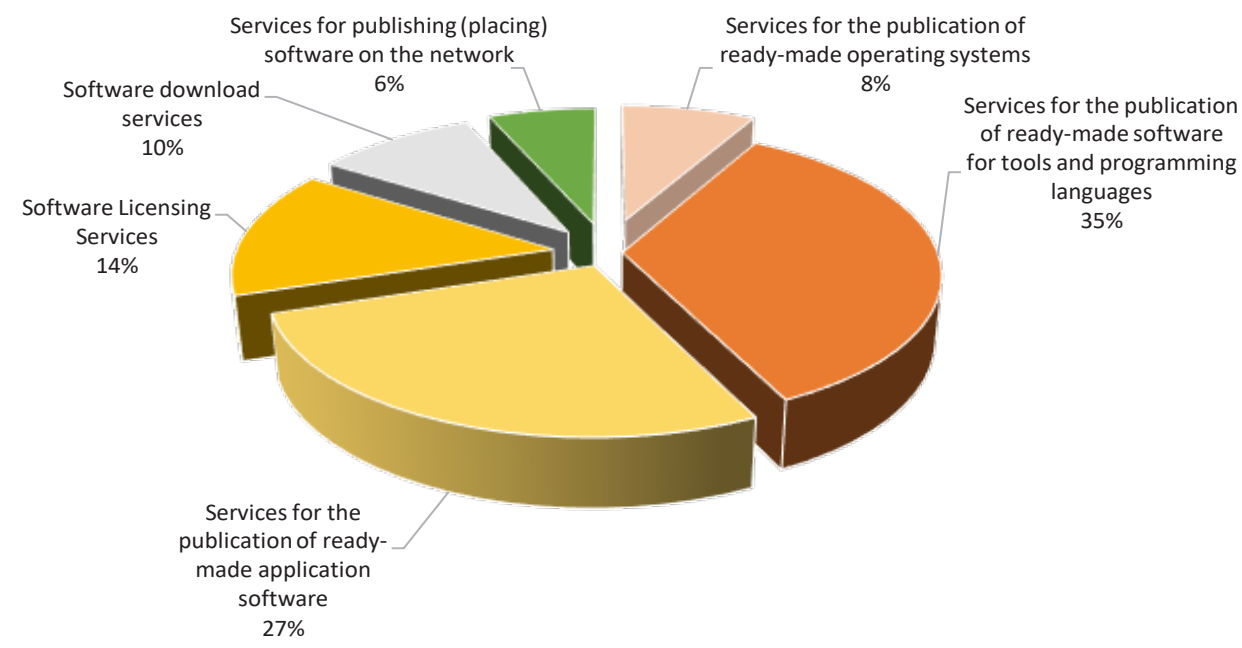

Figure 5 - Structure of produced software in the Republic of Kazakhstan as of 2019 year

Note - Compiled from source [15]

Table 7 - Dynamics of organizations with Internet resources (Internet sites)

\begin{tabular}{|l|c|c|c|c|c|}
\hline \multicolumn{1}{|c|}{ Indicator } & \multicolumn{4}{c|}{ Years } & \multicolumn{3}{c|}{2019} \\
\cline { 2 - 6 } & 2015 & 2016 & 2017 & 2018 & 2019 \\
\hline Number of organizations with Internet resources & 25250 & 21007 & 25950 & 30628 & 25913 \\
\hline Number of organizations, units & 338900 & 353800 & 360300 & 383900 & 412700 \\
\hline Share of organizations with Internet resources, \% & 7,5 & 5,9 & 7,2 & 8,0 & 6,3 \\
\hline \multicolumn{1}{|c|}{ Note - - Compiled from source [15]. } & & & & & \\
\hline
\end{tabular}

Table 8 -Dynamics of the share of organizations with access to the Internet and local corporate and intercorporate resources, $\%$

\begin{tabular}{|l|c|c|c|c|c|}
\hline \multicolumn{1}{|c|}{ Indicator } & \multicolumn{5}{c|}{ Years } \\
\cline { 2 - 6 } & 2015 & 2016 & 2017 & 2018 & 2019 \\
\hline Share of organizations with an Intranet & 18,8 & 27,8 & 31,6 & - & - \\
\hline Share of organizations with an Extranet & 1,5 & 3,7 & 3,2 & - & - \\
\hline Note - Source [15] & & & & & \\
\hline
\end{tabular}

Table 9 - The degree of Internet use by target consumer areas as of 2019 year

\begin{tabular}{|l|c|}
\hline \multicolumn{1}{|c|}{ Directions of Internet use } & Internet use, $\%$ \\
\hline Obtaining information about goods and services & 37,1 \\
\hline Finding information related to healthcare or healthcare services & 16,0 \\
\hline Posting information, instant messaging & 75,7 \\
\hline Download software & 11,8 \\
\hline Downloading movies, images, music & 63,6 \\
\hline Reading online newspapers, magazines & 12,7 \\
\hline Education and training & 14,7 \\
\hline Electronic government services & 30,4 \\
\hline Purchase of goods and services & 15,6 \\
\hline Sale of goods and services & 12,5 \\
\hline \multicolumn{1}{|c|}{ Note - Compiled from source [15]. } & \\
\hline
\end{tabular}


Within the framework of Internet commerce, on the part of Kazakhstani consumers, the maximum share of Internet purchases is concentrated on Kazakhstani companies. This figure is $77 \%$. In second place are Internet purchases of goods and services from CIS companies. This figure is $30,4 \%$. The share of Internet purchases in the EAEU countries and non-CIS countries is $12,1 \%$ and $13,3 \%$, respectively (Figure 6).

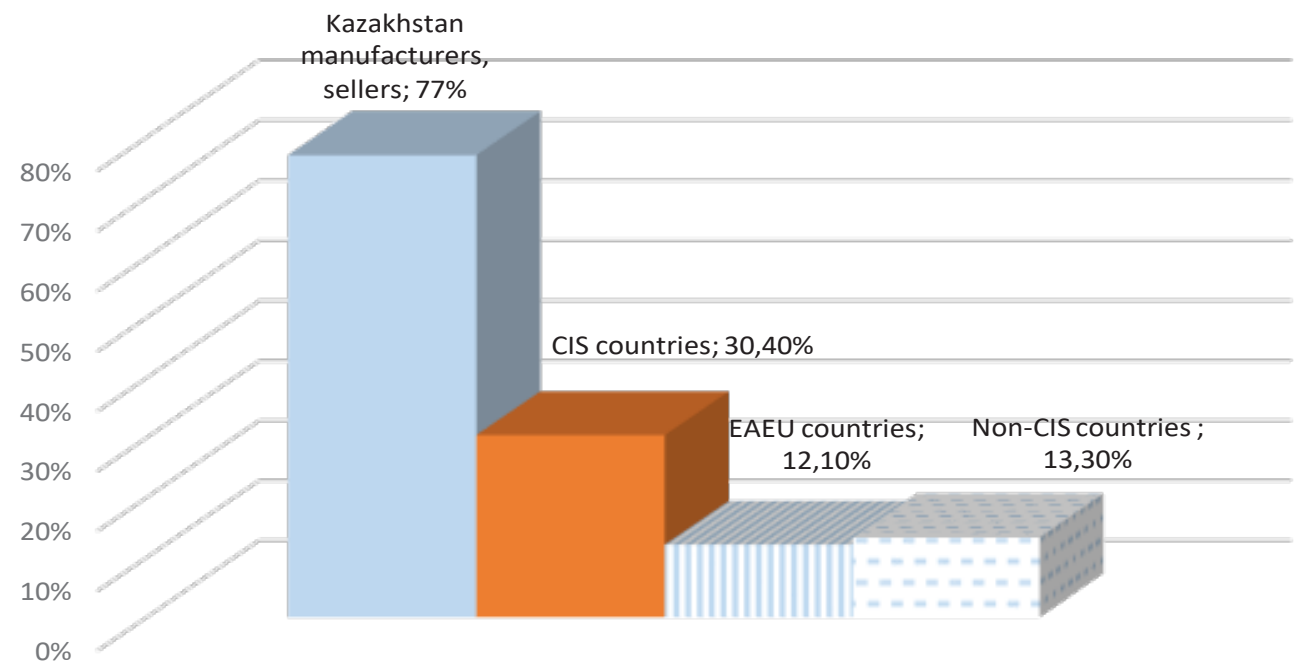

Figure 6 - Structuring of online purchases by the degree of purchase of goods from Kazakhstani and foreign manufacturers as of 2019 year

Note - Compiled from source [15]

To market institutional coordination of e-commerce systems and mechanisms, in the Republic of Kazakhstan in 2019, the Digital Kazakhstan Association was formed, which included the largest trading platforms. The mission of the association is focused on developing a strong e-commerce and trade market in the country [22, $23]$.
The construction and development of the digital economy of the Republic of Kazakhstan is accompanied by the dynamic growth of subjects of digital business and entrepreneurship. From 2015 to 2019 , the number of digital economy entities increased from 7,715 to 10,958 . The largest share is occupied by small enterprises (Table 10).

Table 10 - Dynamics of enterprises operating in sectors of the digital economy

Number of units

\begin{tabular}{|l|c|c|c|c|c|}
\hline \multirow{2}{*}{ Indicator } & \multicolumn{5}{c|}{ Years } \\
\cline { 2 - 6 } & 2015 & 2016 & 2017 & 2018 & 2019 \\
\hline Large enterprises & 73 & 65 & 59 & 42 & 51 \\
\hline Medium enterprises & 96 & 92 & 87 & 89 & 82 \\
\hline Small businesses & 7546 & 8349 & 9188 & 10061 & 10825 \\
\hline Total & 7715 & 8506 & 9334 & 10192 & 10958 \\
\hline \multicolumn{7}{|c|}{ Note - Compiled from source $[15]}$.
\end{tabular}

For 2017 year, the construction of the digital economy has been carried out with the participation of the state. The Republic of Kazakhstan has adopted the State Program "Digital Kazakhstan" for 2018 - 2022, which involves the intensification of digitalization of particularly important industries, an increase in labor productivity, the creation of smart plants and factories, and the development of Internet commerce.

The formation and development of the digital economy of the Republic of Kazakhstan made it possible to form the necessary basic range of services characteristic of the modern digital market (Table 11). 
Table 11 - Dynamics of the provision of services in the digital market of the Republic of Kazakhstan

\begin{tabular}{|c|c|c|c|c|c|c|}
\hline \multirow[t]{2}{*}{ Indicator } & \multicolumn{5}{|c|}{ Indicator value by years, million tenge } & \multirow{2}{*}{$\begin{array}{l}\text { Growth } \\
\text { rate, } \%\end{array}$} \\
\hline & 2015 & 2016 & 2017 & 2018 & 2019 & \\
\hline $\begin{array}{l}\text { Manufacture of computers and } \\
\text { peripheral equipment }\end{array}$ & 4327,6 & 3210,9 & 2807,3 & 3638,3 & 5537,1 & 127,9 \\
\hline $\begin{array}{l}\text { Manufacture of electronic } \\
\text { components and computer } \\
\text { motherboards }\end{array}$ & 2226,2 & 159,8 & 124,7 & 11,3 & 426,9 & 19,2 \\
\hline Internet access services & 190437,5 & 206418,7 & 228686,1 & 243322,7 & 282270,8 & 148,2 \\
\hline Software release & 995,2 & 1175,8 & 2864,1 & 2422,5 & 1730,5 & 173,9 \\
\hline Digital communication services & 702148,0 & 722217,4 & 752332,0 & 782459,1 & 854566,4 & 121,7 \\
\hline Computer programming, consulting & 117383,0 & 141501,9 & 183895,4 & 209057,1 & 277711,9 & 236,6 \\
\hline $\begin{array}{l}\text { Services for the placement and } \\
\text { processing of data, placement of } \\
\text { web portals }\end{array}$ & 45021,5 & 62426,7 & 79449,7 & 102201,8 & 139263,2 & 309,3 \\
\hline $\begin{array}{l}\text { Repair of computers and digital } \\
\text { communication equipment }\end{array}$ & 17367,6 & 18754,8 & 19230,2 & 22682,1 & 31598,1 & 181,9 \\
\hline Total & 1079906,6 & 1155866,0 & 1269389,5 & 1365794,9 & 1593104,9 & 147,5 \\
\hline
\end{tabular}

The formation of a basic range of services typical for the construction and development of the digital economy has created all the necessary foundations for its integration into the traditional (classical) economy, while the digitalization of business processes, the construction of systems, e-commerce mechanisms have become the target for most enterprises, firms, companies.
In digital business and entrepreneurship, there is a positive trend in the efficiency of production and economic activities. The growth in profitability in the strategic period increased from $7.6 \%$ to $18 \%$. At the same time, the share of profitable enterprises significantly predominates (Table 12).

Table 12 - Indicators of the efficiency of functioning of subjects of the digital economy

\begin{tabular}{|l|c|c|c|c|c|}
\hline \multirow{2}{*}{ Indicator } & \multicolumn{5}{|c|}{ Years } \\
\cline { 2 - 6 } & 2015 & 2016 & 2017 & 2018 & 2019 \\
\hline $\begin{array}{l}\text { Gross domestic product, million } \\
\text { tenge }\end{array}$ & 40884133,6 & 46971150,0 & 54378857,8 & 61819536,4 & 69532626,5 \\
\hline $\begin{array}{l}\text { Total volume of services on the } \\
\text { digital market, million tenge }\end{array}$ & 1079906,6 & 1155866,0 & 1269389,5 & 1365794,9 & 1593104,9 \\
\hline $\begin{array}{l}\text { Contribution of the digital economy } \\
\text { to GDP, \% }\end{array}$ & 2,64 & 2,46 & 2,33 & 2,21 & 2,29 \\
\hline $\begin{array}{l}\text { Average profitability of enterprises } \\
\text { operating in the sectors of the digital } \\
\text { economy, \% }\end{array}$ & 7,6 & 8,3 & 10,0 & 18,2 & 18,0 \\
\hline Share of unprofitable enterprises, \% & 26,6 & 29,0 & 28,7 & 23,0 & 23,3 \\
\hline Share of profitable enterprises, \% & 73,4 & 71,0 & 71,3 & 76,9 & 76,7 \\
\hline \multicolumn{7}{|l|}{ Note - Compiled from source [15, 24]. } \\
\hline
\end{tabular}

Despite the dynamic development of Kazakhstan's digital economy, its overall total contribution to economic growth remains insignificant and cyclical. The volumes of production in the sectors of the digital economy in the total GDP of the country, from 2015 to 2019 , ranged from $2.64 \%$ to $2.29 \%$ (Table 12 ). This trend, considering foreign experience, shows that the digital economy of Kazakhstan has significant reserves for its contribution to economic growth.

The conducted studies show that the evolution of the economic and organizational foundations of 
the digital economy of the Republic of Kazakhstan is associated with certain problems that are inevitable during transformational transformations. In the field of analysis of the economic foundations of the formation of the digital economy, the following problems were identified:

- insufficiently intensive trends in the formation of supply and demand in the digital market;

- significant influence of inflationary processes on the cyclical nature of supply and demand for computer technology;

- insufficient reserves of investment opportunities in expanding the computer equipment park of organizations, enterprises, firms, companies;

- a high level of dependence of the digital economy on the import of computer equipment and components.

In the field of organizational foundations for building a digital economy, it is relevant to identify the following problems:

- significant reserves for building the corporate foundations of the digitalization of the economy (low level of provision of internal digital Internet communications of Kazakhstani enterprises);

- significant reserves for the development of production capacities to produce computers and digital electronics in the country, including through effective mechanisms for technology transfer.

To solve these problems at regional levels, there can be:

- developed special indicative programs for infrastructural digital development of enterprises, firms, companies. The main priority in this case should be focused on the small and medium-sized business sector;

- strategies have been developed to attract and finance investments in the expansion of the corporate park of computer equipment.

The above-presented priorities can be taken for implementation by the Directorates of Digital Technologies newly created in the regions of the Republic of Kazakhstan.

\section{Conclusion}

In a complex, research and analysis of the economic and organizational foundations for building and developing the digital economy shows that a solid foundation has been formed in the Republic of Kazakhstan for the digitalization of the entire economic system, as well as the foundations for building and increasing the market for digital products and technologies, creating and developing business entrepreneurship in all sectors of the digital economy. In a strategic perspective, a phased increase in the development trends of the digital economy should be accompanied by its close integration with an innovative economy focused on the production of products with high added value in manufacturing, including on the principle of "Internet of things". A special role in the development of the digital economy should be given to issues of state support for the digitalization of industries and sectors of the economy at the regional levels. As part of state support for the digital economy of Kazakhstan, the main priority should be focused on creating a solid foundation for the electronic digital industry and gradually moving away from the import of computer equipment. These issues can be resolved in the coming strategic and long-term periods.

\section{References}

1. Dneprov M.Yu., Mikhailyuk O.V. Digital economy as a new economic category // Problems of innovative economics. - 2019.- T. 9, N.4 - p. 1279-1294.

2. Negroponte N. Being Digital. Knopf. Paperback edition, 1996. $-120 \mathrm{p}$.

3. Digital economy: how experts understand this term. URL: https://ria.ru/20170616/1496663946.html (date accessed: 27.01.2021).

4. Kaluzhsky ML Marketing networks in e-commerce: an institutional approach. Monograph / M.L. Kaluga. - M .: Berlin: Direct-Media, 2014. - 402 p.

5. Kelly K. New Rules for the New Economy: 10 radical strategies for a connected world / K. Kelly. New York: Viking, 1998. - 224 p.

6. Gasanov G.A., Gasanov T.A. Digital economy as a new direction of economic theory // Regional problems of economic transformation. - 2017. - N 6 . - p. 4-10.

7. Introduction to the "Digital" economy / A.V. Keshelava, V.G. Budanov, V.Yu. Rumyantsev and others; under total. ed. A.V. Keshelava; ch. "Digital." cons. I.A. Zimnenko. - VNIIGeosystem, 2017. - 28 p. (On the verge of a "digital future". Book one).

8. Baranov D.N. The essence and content of the category "digital economy" // Bulletin of the Moscow University named after S. Yu. Witte. Series 1 . Economics and Management. - 2018. - N 2 (25). - p. 15 - 23.

9. Litvinenko V. S. Digital Economy as a Factor in the Technological Development of the Mineral Sector // Nat Resour Res. - 2020. - N. 29. - p. 1521-1541. URL: https://doi.org/10.1007/s11053-019-09568-4 (date accessed: 20.02.2021).

10. Nosova S.S., Makar S.V., Gerasimenko T.I., Medvedeva O.E., Abdulov R.E. Transformation of business models in the mode of the Russian economy digitalization // Revista ESPACIOS. - 2020. Vol. 39 (Number 24). - P. 27. URL: http://revistaespacios.com/ a20v41n12/20411222.html (date accessed: 05.02.2021).

11. Verhoef P.C., Broekhuizen T. Bart Ya., Bhattacharya A., Dong J.Q., Fabian N., Haenleinc M. Digital transformation: A multidisciplinary reflection and research agenda // Journal of Business Research. - 2021. - Volume 122. - p. 889-901. URL: https://doi. org/10.1016/j.jbusres.2019.09.022 (date accessed: 20.02.2021). 
12. Ertz M., Boily E. The rise of the digital economy: Thoughts on blockchain technology and cryptocurrencies for the collaborative economy // International Journal of Innovation Studies. 2019. - Volume 3, Issue 4. - p. 84-93. URL: https:// doi.org/10.1016/j.ijis.2019.12.002 (date accessed: 20.02.2021).

13. Kazakhstani market of computer technology. State and trends of the Kazakhstani IT market.URL: https://profit.kz/articles/520/Kazahstanskij-rinokkomputernoj-tehniki/ (date accessed: 27.01.2021).

14. Personal computers are in demand. The first Eurasian business magazine "Business World. Kazakhstan” 2019. URL: http://businessmir. kz/2019/10/21/personalnye-kompyutery-polzuyutsyasprosom/ (date accessed: 27.01.2021).

15. Development of communications and information and communication technologies in the Republic of Kazakhstan. Statistical collection. NurSultan. 2020., 51 p.

16. PRO fixed assets and their reflection in the configuration "1C: Accounting 8 for Kazakhstan", rev. 3.0. ТОО “1C-Рейтинг”. URL: https://prolc.kz/articles/ kpn/vychety-po-fiksirovannym-aktivam/ (date accessed: 27.01.2021)
17. Production and logistics at JSC "Logicom". URL: http://corp.logycom.kz/ru/company/produce/ (дата обращения: 27.01.2021).

18. The production of computer equipment was launched in Petropavlovsk. URL: https://forbes.kz/ news/2020/08/14/newsid_231375 (date accessed: 27.01.2021).

19. Kazakhstan in numbers. Brochure. Astana. 2016. - 22 p.

20. Kazakhstan in numbers. Brochure. Astana. 2017. - 20 p.

21. Kazakhstan in numbers. Brochure. Nur-Sultan. 2020. -22 p.

22. E-commerce in Kazakhstan: the regulator and business discussed the prospects for the development of the industry. URL: https://profit.kz/news/53325/ Elektronnaya-kommerciya-v-Kazahstane-regulyatori-biznes-obsudili-perspektivi-razvitiya-otrasli/ (date accessed: 27.01.2021).

23. Association "Digital Kazakhstan". URL: https://dka.kz/mission (date accessed: 27.01.2021).

24. Kazakhstan in 2019. Statistical Yearbook. NurSultan. 2020. - 499 p.

\section{Information about the authors}

Beisembay Yersultan - corresponding author, Toraighyrov University, 140000, Republic of Kazakhstan, Pavlodar city, Lomova street 64, PhD candidate of the Department of Economics. E-mail: Beisembai_ersultan@mail. ru; https://orcid.org/0000-0002-5046-030X

Ernazarov Takhir Yazdurdievich - Toraighyrov University, 140000, Republic of Kazakhstan, Pavlodar city, Lomov street 64, candidate of technical sciences, associate professor of economics, professor of the Department of Economics. E-mail: denat_et@mail.ru; https://orcid.org/0000-0002-9357-0103

\section{Авторлар туралы мәліметтер}

Бейсембай Ерсұлтан - хат-хабаршы авторы,, Торайғыров университеті, 140000, Қазақстан Республикасы, Павлодар қаласы, Ломова көшесі 64, экономика кафедрасының PhD кандидаты. Электрондық пошта: Beisembai_ersultan@mail.ru; https://orcid.org/0000-0002-5046-030X

Эрназаров Тахир Яздурдиевич - Торайғыров университеті, 140000, Қазақстан Республикасы, Павлодар қаласы, Ломов көшесі 64, техника ғылымдарының кандидаты, экономика кафедрасының доценті, экономика кафедрасының профессоры. E-mail: denat_et@mail.ru; https://orcid.org/0000-0002-9357-0103

Дата поступления рукописи: 09.02.2021

Прошла рецензирование: 22.02.2021

Принято решение о публикации: 05.03.2021

Received: 09.02.2021

Reviewed: 22.02.2021

Accepted: 05.03.2021

Қарастыруға қабылданды: 09.02.2021

Рецензиялауды өтті: 22.02.2021

Жариялауга қабылданды: 05.03.2021 